\title{
S100 Protein in Serum as a Prognostic Marker for Cerebral Injury in Term Newborn Infants with Hypoxic Ischemic Encephalopathy
}

\author{
KRISTINA THORNGREN-JERNECK, CHRISTER ALLING, ANDREAS HERBST, \\ ISIS AMER-WÅHLIN, AND KAREL MARSAL \\ Department of Pediatrics [K.T-J.], Department of Obstetrics and Gynecology [A.H.,I.A-W.,K.M.] and \\ Department of Medical Neurochemistry [C.A.], University Hospital, SE-221 85 Lund, Sweden
}

\begin{abstract}
The astroglial protein S100 is an established biochemical marker for CNS injury in the adult. The aim was to investigate whether S100 in serum is a prognostic marker of cerebral injury in term newborn infants with hypoxic ischemic encephalopathy (HIE) after perinatal asphyxia. Serum S100 was measured on postnatal days 1-4 in 62 term infants with birth asphyxia. The infants were classified for HIE and had follow-up for at least 18 mo. Infants with moderate and severe HIE had significantly higher S100 levels on postnatal day $1(p=0.031)$ and day $2(p$ $=0.008)$ than infants with mild or no HIE. The levels of S100 decreased on days 2 and 3 in all infants with HIE. The median S100 level on postnatal day 1 was higher in nine infants who died neonatally and in 10 infants who developed cerebral palsy (CP), compared with 43 infants with no signs of impairment at follow up, $14.0(0.5-60.0) \mu \mathrm{g} / \mathrm{L}, 20.7(0.2-64.0) \mu \mathrm{g} / \mathrm{L}$ and $5.5(0.7-$ 120.0) $\mu \mathrm{g} / \mathrm{L}$, respectively. A level of $\mathrm{S} 100$ above $12 \mu \mathrm{g} / \mathrm{L}$ the first day of life was significantly more frequent in infants who
\end{abstract}

\section{ABSTRACT}

died or developed CP than in infants with no impairment at follow up $(p=0.02)$. Increased S100 levels were significantly inversely correlated with perinatal $\mathrm{pH}$ in the infants and associated with abnormal CTG at admission to the labor ward. Early determination of serum S100 may reflect the extent of brain damage in infants with HIE after asphyxia. (Pediatr Res 55: 406-412, 2004)

\section{Abbreviations}

$\mathbf{C P}$, cerebral palsy

CSF, cerebrospinal fluid

CTG, cardiotocography

FHR, fetal heart rate

HIE, hypoxic ischemic encephalopathy

S100, S100 protein including the subunits $\alpha \beta$ and $\beta \beta$

aEEG, amplitude integrated EEG

GFAP, glial fibrillary acidic protein
Birth asphyxia remains a considerable problem in perinatal medicine with an incidence around $0.6-0.8 \%$ of births $(1-3)$. About half of these infants develop hypoxic ischemic encephalopathy (HIE) $(2,4)$. Those with moderate and severe HIE are at high risk of developing cerebral palsy (CP) (5-8). Prognostic assessment of brain injury after perinatal asphyxia will become essential for proper selection concerning early cerebroprotective treatment, which might be a likely option in the near future $(9,10)$. Several biochemical markers in cerebrospinal fluid (CSF) have been associated with cerebral complications in infants after perinatal asphyxia (11-14) and recently

Received October 2, 2002; accepted June 10, 2003.

Correspondence: Kristina Thorngren-Jerneck, MD, PhD, Department of Pediatrics, University Hospital, Lund University, SE-221 85 Lund, Sweden; e-mail: kristina.thorngren-jerneck@pedi.lu.se.

Supported by grants from the Swedish Medical Research Council (Project No 4732), the Axel and Margaret Ax:son-Johnson Foundation, the Royal Physiographic Society, the First of May Flower Annual Foundation, the Linnéa and Josef Carlsson Foundation, the Sven Jerring Foundation, the Segerfalk Foundation and grants from The Medical Faculty of Lund University.

DOI: 10.1203/01.PDR.0000106806.75086.D3 also S100 in CSF (15). A prognostic marker in serum would be of great value.

S100 is a calcium binding protein present in the CNS. The dimers $\alpha \beta$ and $\beta \beta$ of S100 are mainly specific for the nervous system and present chiefly in the astroglial cells of the CNS $(16,17)$. S100 $\alpha \alpha$ is present in many organs outside the CNS and will not be discussed in this report, where S100 will be used for the brain-specific S100 with subunits $\alpha \beta$ and $\beta \beta$.

The astroglial protein $\mathrm{S} 100$ is an established biochemical marker for CNS injury in the adult, in whom increased levels of S100 in CSF have been reported after cerebral insults (18, 19). S100 in blood has been shown to be a marker of brain damage in adult stroke $(20,21)$ and a potential marker for cerebral events after cardiac arrest (22).

There are a few studies on S100 in serum of infants. S100 in serum has been shown to be a possible marker of postperfusion cerebral injury after pediatric cardiac operations (23). In preterm infants with intraventricular hemorrhage concentrations of S100 in blood were elevated, before a radiologic assessment of hemorrhage could be performed (24). Circulating S100 
protein was increased in IUGR fetuses and correlated with cerebral hemodynamics, suggesting that it may represent an index of cerebral cell damage in the perinatal period (25). Elevated S100 in serum measured during the first $24 \mathrm{~h}$ after asphyxia has been shown to be associated with HIE in term infants (26). We have recently described reference values of S100 in cord blood of newborn term infants with uncomplicated delivery (27), and in a pilot study we also found the increased S100 to correlate with the degree of HIE (28).

The aim of the present study was to further investigate whether increased S100 levels in serum are correlated with the grade of HIE after perinatal asphyxia, and more specifically whether increased S100 predicts the cerebral injury and subsequent cerebral palsy. We also aimed to relate the level of $\mathrm{S} 100$ to $\mathrm{pH}$ at birth, and to the severity and timing of fetal distress during labor as indicated by CTG abnormalities.

\section{PATIENTS AND METHODS}

Study group. Sixty-two term newborn infants with birth asphyxia born between November 1995 and November 1999, treated at the Neonatal Intensive Care Unit (NICU), Lund University Hospital, Sweden, were prospectively included in the study. The diagnosis of asphyxia was made on clinical signs during the first hours of life, together with acid-base status.

The following inclusion criteria were used: (all necessary)

$1 /$ Term newborn ( $\geq 36$ completed gestational weeks), $2 / \mathrm{Ap}$ gar score $<7$ at $5 \mathrm{~min}$ or other clinical signs of perinatal asphyxia together with umbilical artery acidosis $(\mathrm{pH}<7.10$ and/or Base Deficit (BD) $>12 \mathrm{mmol} / \mathrm{L}$ ), and 3) Clinical signs of asphyxia necessitating transfer to neonatal intensive care unit.

Neonates with severe infections (sepsis, pneumonia) or severe malformations were excluded and also an infant with myotonic dystrophy.

Clinical data on the infants are shown in Table 1. All infants were neurologically examined daily during the first week of life and classified according to the degree of HIE (5) into mild, moderate or severe HIE. All infants had neurologic follow-up examinations to the age of at least $18 \mathrm{mo}$. Assessment of outcome was done according to items from Amiel-Tison (29). Children were classified as having CP or no signs of impairment at 18 mo. CP was identified and classified according to the criteria of Hagberg et al. (30).
The study was approved by the Research Ethics Committee of the Faculty of Medicine, University of Lund. Informed consent was obtained from the parents.

Obstetric data. Obstetrical data are shown in Table 2. Most patients were delivered operatively for signs of fetal distress.

Control group. Serum samples from cord blood (arterial and venous blood mixed) from a control group of 32 term newborn infants, gestational age, median (range) 40 (37-42) weeks, were collected before the study started. The control infants, all with Apgar score $\geq 9$ at 1, 5 and 10 min, were born 1995-96 after uncomplicated vaginal delivery with a mean umbilical artery $\mathrm{pH}$ of 7.26 (SD 0.07) and a mean BD of $5 \mathrm{mmol} / \mathrm{L}$ (SD 2.7).

Blood sampling for $\mathbf{S 1 0 0}$. The blood samples were obtained at postnatal day 1 (range $1-19 \mathrm{~h})$, day $2(24-48 \mathrm{~h})$ and day 3 or 4 (48-96h) hours after birth. The first sample was taken when the routine blood samples were obtained after admission to the NICU. Samples were collected from a catheter, already inserted for clinical purpose in the umbilical artery or in the umbilical vein.

Cardiotocography (CTG). The 54 labor CTG records that were available from the asphyxia group, were evaluated by two expert interpreters (A.H., I.A-W), who were blinded to the outcome of the infants by mixing the records with the 26 records available from the control group. The CTG traces were classified according to F.I.G.O. guidelines (31), and categorized according to the occurrence and duration of abnormalities into five groups: 1/abnormal at admission, 2 /abnormal for more than $60 \mathrm{~min}, 3 / \mathrm{abnormal}$ for $15-59 \mathrm{~min}$, 4/abnormal less than $15 \mathrm{~min}$ and 5/never abnormal.

Acid base measurements. During the study period, umbilical artery blood was routinely assessed for acid-base analysis at all deliveries in Lund, and in the majority of the referring hospitals. If no umbilical blood sample was available $(n=10)$, the first postnatal acid-base value (within the first hours postnatal age) of the infant was considered. In three infants no acid base-value was available.

Cases were categorized as having acidosis if cord artery blood $\mathrm{pH}$ was $\leq 7.10$ ( $2 \mathrm{SD}$ below the mean of the population), and as metabolic acidosis if BD was $>12.0 \mathrm{mM}$ ( 2 SD above the mean of the population). If only umbilical vein blood was available, the case was classified as acidemic if $\mathrm{pH}$ was $<7.10$, otherwise it was classified as unknown.

Table 1. Characteristics on the 62 infants with perinatal asphyxia

\begin{tabular}{|c|c|c|c|c|c|}
\hline & $\begin{array}{l}\text { All infants } \\
(n=62)\end{array}$ & $\begin{array}{l}\text { No HIE } \\
(n=5)\end{array}$ & $\begin{array}{l}\text { Mild HIE } \\
(n=21)\end{array}$ & $\begin{array}{l}\text { Moderate HIE } \\
\quad(n=24)\end{array}$ & $\begin{array}{l}\text { Severe HIE } \\
(n=12)\end{array}$ \\
\hline Gestational age at birth (w) & $40(36-42)$ & $40(39-41)$ & $40(36-42)$ & $40(36-42)$ & $40(37-42)$ \\
\hline Birth weight $(\mathrm{kg})$ & $3.6(2.5-5.5)$ & $3.6(2.8-5.0)$ & $3.5(2.5-4.6)$ & $3.5(2.9-5.1)$ & $4.0(2.8-5.5)$ \\
\hline Gender $(\mathrm{M} / \mathrm{F})$ & $30 / 32$ & $3 / 2$ & $9 / 12$ & $10 / 14$ & $8 / 4$ \\
\hline Inborn/outborn & $36 / 26$ & $5 / 0$ & $16 / 5$ & $10 / 14$ & $5 / 7$ \\
\hline Perinatal arterial $\mathrm{pH}^{*}$ & $6.99(6.5-7.4)$ & $7.04(6.98-7.20)$ & $7.05(6.78-7.40)$ & $6.98(6.68-7.29)$ & $6.86(6.68-7.06)$ \\
\hline
\end{tabular}

Values are median (range) or $n$.

* pH missing in 2 infants with mild HIE and in 1 with moderate HIE.

$\dagger$ BD missing in 3 infants with mild HIE, 2 with moderate HIE and 2 with severe HIE. 
Table 2. Obstetrical data in cases with asphyxia

\begin{tabular}{lc}
\hline \multicolumn{1}{c}{ Clinical data } & $N=62$ \\
\hline Admitted for & $38(61 \%)$ \\
Labor & $12(19 \%)$ \\
Rupture of membranes & $11(18 \%)$ \\
Pregnancy complications & $1(1 \%)$ \\
Delivered at home & $14(23 \%)^{*}$ \\
Fever during labor & $37(60 \%)$ \\
Induction or augmentation of labor with & \\
oxytocin & \\
Amniotic fluid & $24(39 \%)$ \\
Clear & $30(48 \%)$ \\
Meconium stained & $5(8 \%)$ \\
Blood-stained & $3(5 \%)$ \\
Unknown & \\
Mode of delivery & $19(31 \%)$ \\
Spontaneous vaginal & $12(19 \%)$ \\
Instrumental delivery & $31(50 \%) \dagger$ \\
Cesarean section & \\
Presentation & $11(18 \%) \dagger$ \\
Breech & \\
Indication for operative delivery $(N=43)$ & $31(72 \%)$ \\
Pathological CTG-trace & 1 \\
Abruptio placentae & 1 \\
Uterine rupture & 2 \\
Cord prolapse & 1 \\
Stuck head (breech) & $6(10 \%)$ \\
Dystocia & \\
\hline
\end{tabular}

* Maximum temperature in labor above $38^{\circ} \mathrm{C}$. Temperature documented in 47 patients.

$\dagger$ In three of these cases, a failed attempt of vacuum extraction had been performed.

† Seven were vaginally delivered, three by emergency caesarean due to cord prolapse (2) or threatening asphyxia (1).

S100 analysis. The serum samples were analyzed using a commercially available monoclonal two-site immunoradioactive assay detecting $\alpha \beta$ and $\beta \beta$ dimers (Sangtec 100, Sangtec Medical, Bromma, Sweden). Duplicate serum samples of $200 \mu \mathrm{L}$ were used to identify and quantify the proteins. The samples were analyzed either by a Radio immuno assay (S100 IRMA) (1996-1997) or a monoclonal two-site immunoluminometric assay (LIA-MAT Sangtec ${ }^{\mathrm{R}}$ 100) (1998-1999). The detection level for $\mathrm{S} 100$ values was $0.12 \mu \mathrm{g} / \mathrm{L}$. The precision for S100 LIA-MAT was, (coefficient of variation; CV) $8.1 \%$ for low values $(0.25 \mu \mathrm{g} / \mathrm{L})$ and $5.7 \%$ for high values $(2.8 \mu \mathrm{g} / \mathrm{L})$ and for S100 IRMA, $9.2 \%$ and $7.6 \%$, respectively.

Statistical analysis. Nonparametric tests were used. Correlations were made by Spearman's test, and for comparison of continuous variables betweeen groups, Mann-Whitney test was used. When using statistics for categorical data (Pearson $\chi^{2}$ or Fisher's exact test) we assumed $\mathrm{S} 100<12 \mu \mathrm{g} / \mathrm{L}$ as low and $\mathrm{S} 100 \geq 12 \mu \mathrm{g} / \mathrm{L}$ as high values. A $p$-value $<0.05$ was regarded as significant.

\section{RESULTS}

\section{Clinical Outcome}

Neonatal outcome. Among the 62 asphyxiated infants, 21 infants developed mild HIE, 24 moderate and 12 severe HIE. Five infants had no abnormal neurologic signs during the neonatal period. Nine infants, all with severe HIE, died during the neonatal period (Table 1)

Follow-up. The clinical follow-up time of the infants was at least 18 mo. Ten infants, all with moderate or severe HIE developed $\mathrm{CP}$, and one of them died at 1.5 years. 43 infants had no signs of $\mathrm{CP}$ at $18 \mathrm{mo}$ of age.

\section{S100}

All serum samples for S100 were of good quality without hemolysis. Fifty infants had S100 values from day 1. In 41 infants there were values from day 2 and in 45 infants there were values from day 3 or 4 . Infants with moderate and severe HIE had significantly higher S100 on postnatal day $1(p=$ $0.031)$ and day $2(p=0.008)$, than infants with mild or no HIE (Fig. 1).

In all infants with HIE the levels of S100 were highest on postnatal day 1 , decreased on day 2 and furthermore on day 3 (Fig. 1).

On postnatal day 1 median (range) serum values of S100 were as follows: mild HIE $(n=16) 5.95(1.4-118.0) \mu \mathrm{g} / \mathrm{L}$, moderate HIE $(n=19) 26.0(0.2-120.0) \mu \mathrm{g} / \mathrm{L}$ and severe HIE $(n=10) 10.2(0.5-64.0) \mu \mathrm{g} / \mathrm{L}$. In five infants with no signs of HIE during the neonatal period S100 was $1.8(1.0-4.5) \mu \mathrm{g} / \mathrm{L}$ (Fig. 1).

Six of nine infants who developed CP had very high serum levels of S100 on day 1 (Fig. 2). Median (range) S100 on day 1 in the nine infants who developed CP was $20.7(0.2-64.0)$ $\mu \mathrm{g} / \mathrm{L}$, to compare with $5.5(0.7-120.0) \mu \mathrm{g} / \mathrm{L}$ in 34 infants with no signs of impairment at 18 mo follow up. Seven infants who died during the neonatal period had S100 14.0 (0.5-60.0) $\mu \mathrm{g} / \mathrm{L}$. On postnatal day 2 the infants who died neonatally had higher median (range) S100 $11.0(0.4-71.3) \mu \mathrm{g} / \mathrm{L}$ than infants with $\mathrm{CP}$ at follow up $3.8(0.8-36.0) \mu \mathrm{g} / \mathrm{L}$. The infants with no impairment at follow up had S100, median (range), 2.3 (0.4110.0) $\mu \mathrm{g} / \mathrm{L}$ at day 2, (Fig. 2).

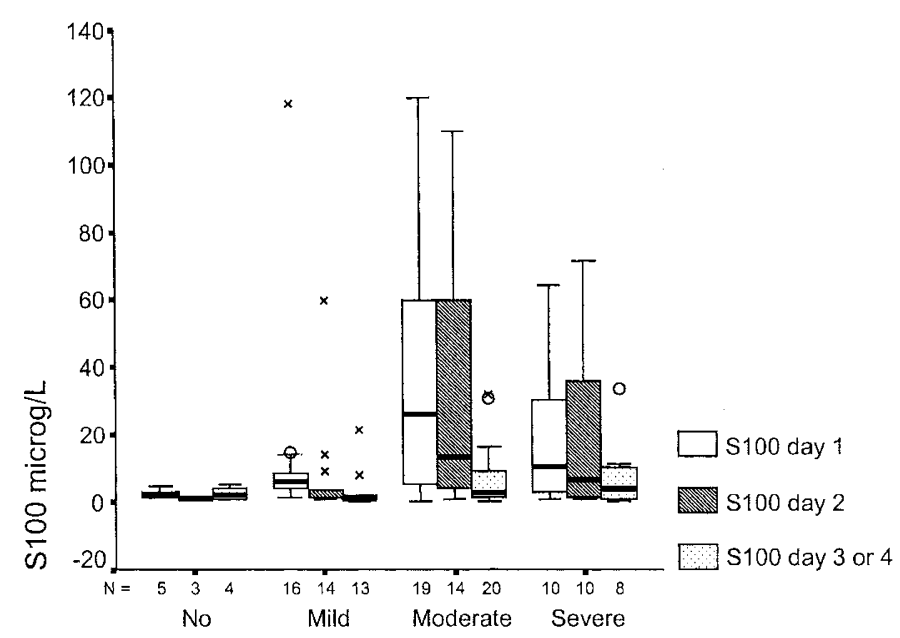

HIE

Figure 1. Box plot with median serum levels, (quartiles, 5th and 9th percentiles, and extreme values) of protein S100 on day 1, 2 and 3 or 4, in relation to the degree of hypoxic ischemic encephalopathy (HIE) during the neonatal period, in term infants with birth asphyxia. 


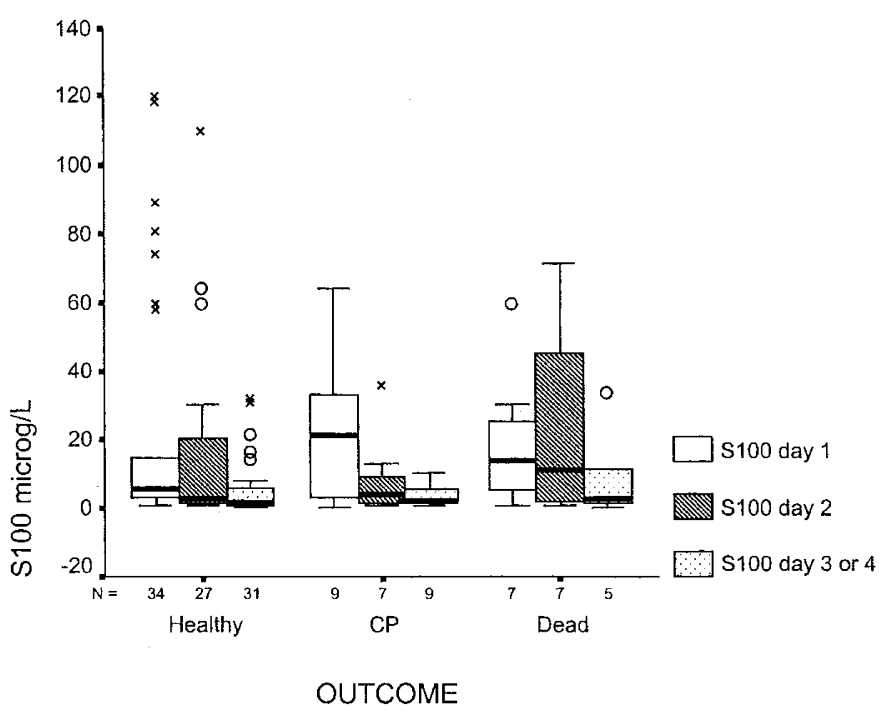

Figure 2. Box plot with median serum levels, (quartiles, 5th and 9th percentiles, and extreme values) of protein S100 on day 1, 2 and 3 or 4 of term infants with birth asphyxia, in relation to outcome (healthy, cerebral palsy (CP) or dead) during the neonatal period.

A level of S100 above $12 \mu \mathrm{g} / \mathrm{L}$ on postnatal day 1 and/or day 2 was significantly more frequent in infants who died neonatally or developed $\mathrm{CP}$, than in infants who were healthy at 18 mo $(p=0.022)$.

Fig. 3 shows the declining values of S100 on day 1-3 of 14 infants with CTG changes appearing during the the last hour of labor.

\section{S100 in the Control Group}

The median serum value of S100 in cord blood (artery and vein mixed) of the control group, 32 infants born after normal vaginal delivery, was $1.37 \mu \mathrm{g} / \mathrm{L}$ (range 0.20 - 3.02).

\section{Acid Base Measurement}

Of neonates with available cord artery $(n=48)$ or cord vein $(n=1)$ acid base status, 37 had acidemia of whom, 30 had

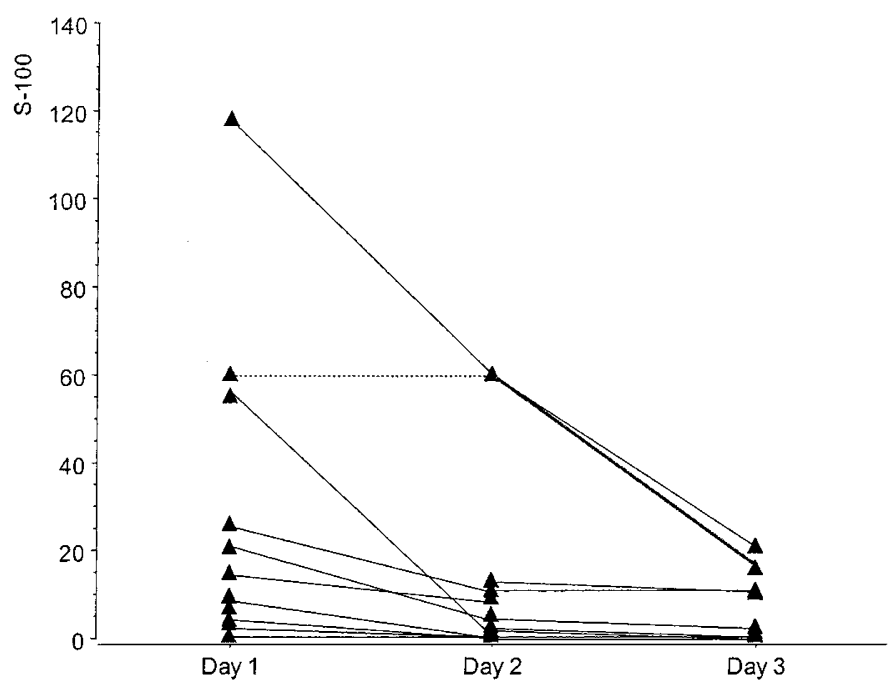

Figure 3. Individual $\mathrm{S} 100$ levels (microg/L) on days $1-3$ in 14 cases where cardiotocography (CTG) changes appeared during the last hour of labor. metabolic acidemia. The rate of acidemia at birth was significantly higher in those with moderate and severe HIE (24 of 27) than in those with mild or no HIE (13 of $22 ; p=0.02$ ). Sixteen of 17 infants with adverse outcome (neonatal death or CP) had umbilical acidemia at birth compared with 21 of 32 with an uncomplicated long-term outcome $(p=0.02)$. For metabolic acidemia these differences were not statistically significant.

The rate of high $\mathrm{S} 100$ values $(>12 \mu \mathrm{g} / \mathrm{L}$ during the first three postnatal days) was not significantly higher among neonates with acidemia at birth (14 of 37), compared with those with clinical asphyxia without acidemia at birth ( 3 of $12 ; p=$ $0.4)$.

However, $\mathrm{S} 100>15 \mu \mathrm{g} / \mathrm{L}$ during the first three postnatal days, was significantly higher among infants with perinatal acidemia. ( $p=0.049$, Fisher's exact test).

In all 62 infants with asphyxia except 3 there were acid-base measurement from either the umbilical cord or from the infant within the first hours after birth (Table 1). When calculating with the lowest acid base level at or directly after birth, there was a significant correlation between S100 on day 1 and lowest $\mathrm{pH}(p=0.03)$ and between $\mathrm{S} 100$ and the highest $\mathrm{BD}(p=$ $0.002)$.

\section{CTG}

Retrospective blinded analysis of 54 CTG traces from the study group, revealed abnormal patterns present at admission in 14 cases, and appearing during labor in 33 cases (Table 3). The levels of S100 (maximum levels during the first three days) were significantly higher in cases with CTG abnormalities at admission (median $45.5 \mu \mathrm{g} / \mathrm{L}$ ) compared with those cases of asphyxia with normal CTG at admission (median 4.8 $\mu \mathrm{g} / \mathrm{L} ; p=0.003$ ), and higher in those with any CTG abnormalities (median $8.5 \mu \mathrm{g} / \mathrm{L}$ ) compared with those cases with no CTG abnormalities (median $2.0 \mu \mathrm{g} / \mathrm{L} ; p=0.02$ ) (Table 4). Of the 14 cases with abnormal CTG at admission, 10 had high $(>12 \mu \mathrm{g} / \mathrm{L})$ levels of S100 day $1-3$, whereas only 12 of 47 cases with normal CTG at admission had such high levels $(p=$ $0.01)$.

\section{PREDICTION}

For prediction of neonatal outcome measured as moderate or severe HIE, the sensitivity of S100 >12 $\mu \mathrm{g} / \mathrm{L}$ was $50 \%$, specificity $85 \%$, positive predictive value (PPV) $82 \%$ and negative predictive value (NPV) $55 \%$. For prediction of death or development of CP by $11 / 2$ year, the sensitivity of S100 $>12 \mu \mathrm{g} / \mathrm{L}$ was $58 \%$, specificity $75 \%$, PPV $50 \%$ and NPV $80 \%$. Table 5 describes the prediction for HIE and outcome of S100 $>12 \mu \mathrm{L} / \mathrm{g}$ in combination with acidosis and/or early clinical markers.

\section{DISCUSSION}

The main result of the present study was the considerable increase of protein S100 in serum of infants with birth asphyxia, most pronounced in infants with moderate and severe HIE, neonatal death and cerebral palsy at 18 mo. Furthermore, 
Table 3. Duration of fetal heart rate abnormalities during labor in 54 cases with available CTG traces* in study group, and 26 in the control group

\begin{tabular}{|c|c|c|c|c|c|}
\hline \multirow[b]{2}{*}{ CTG } & \multirow{2}{*}{$\begin{array}{c}\begin{array}{c}\text { Control } \\
\text { group }\end{array} \\
(N=26)\end{array}$} & \multicolumn{4}{|c|}{ Study group } \\
\hline & & $\begin{array}{l}\text { No HIE } \\
(N=5)\end{array}$ & $\begin{array}{l}\text { Mild HIE } \\
(N=18)\end{array}$ & $\begin{array}{l}\text { Moderate HIE } \\
\qquad(N=21)\end{array}$ & $\begin{array}{c}\text { Severe HIE } \\
(N=11)\end{array}$ \\
\hline Abnormal at admission & 0 & 0 & 3 & $8 *(2)$ & $3(3)$ \\
\hline Abnormal $>60$ minutes & 1 & 1 & 3 & $4(1)$ & $3(3)$ \\
\hline Abnormal for $15-59$ minutes & 1 & 2 & 7 & $6(4)$ & $4(4)$ \\
\hline Abnormal $<15$ minutes & 0 & 0 & 2 & 0 & $1(1)$ \\
\hline Normal & 24 & 2 & 3 & 3 & 0 \\
\hline
\end{tabular}

The numbers of cases with adverse outcome (dead or CP at follow up) are given in brackets.

* One case with documented severe bradycardia at admission was included as a pathological fetal heart rate, despite that no CTG was taken, since in this case auscultation and clinical signs of placental abruption made the diagnosis of fetal distress at admission evident.

Table 4. Maximum blood levels of $S-100$ (microg/L) from postnatal days $1-3$, in relation to $C T G$ pathology* in cases with asphyxia

\begin{tabular}{lclc}
\hline \multirow{2}{*}{ CTG } & \multicolumn{2}{c}{ S100 } & \\
\cline { 2 - 3 } & Median (range) & $\mathrm{p}$ & S-100 $>12.0$ \\
\hline Abnormal at admission $(N=14) *$ & $45.5(0.9-120)$ & 0.003 & $10(71 \%) \dagger$ \\
Abnormal $>60$ minutes $(N=11)$ & $5.7(0.2-64)$ & 0.5 & $2(20 \%)$ \\
Abnormal for 15-59 minutes & $4.5(0.2-118)$ & 0.4 & $6(32 \%)$ \\
$\quad(N=19)$ & & & \\
Abnormal $<15$ minutes $(N=3)$ & $14.8(7.0-30)$ & 0.4 & $2(67 \%)$ \\
Normal $(N=8)$ & $2.0(0.6-14.0)$ & 0.02 & $2(25 \%)$ \\
\hline
\end{tabular}

P-values are presented for each group in comparison to all other groups together.

* One case with auscultated severe bradycardia at admission (and clinical signs of abruption of the placenta) was included as a pathological fetal heart rate, despite that no CTG was taken, since in this case an abnormal heart rate and clinical signs of fetal hypoxia were evident at admission.

$\dagger p=0.01$ compared to all other groups together.

increased S100 levels were inversely correlated with perinatal $\mathrm{pH}$ in the infants and associated with abnormal CTG at admission to the hospital.

A few studies on serum S100 in newborn infants with perinatal asphyxia have shown a correlation with short-term neonatal outcome measured as $\operatorname{HIE}(26,32)$. Increased levels of S100 were associated with moderate and severe HIE. Previously we showed in a pilot study S100 to be a potential marker for the severity of HIE (28). To our knowledge, no study on infants has shown any association between increased serum levels of S100 and the subsequent cerebral injury at follow-up.

The healthy controls in the present study, showed median values of S100 in mixed cord blood comparable to what we have shown recently (27). Those values are higher than values from healthy adults. There are certain possibilities to explain this difference but they are still to be elucidated. S100 beta has been reported to be involved in the proliferation and differentiation of astrocytes (33). S100 $\beta$ is an astrocyte-derived neurotrophic protein that has a well characterized trophic role in promoting survival and neuritic outgrowth from specific neuronal populations during development of the nervous system (34). Infants have around term age a rapid brain growth and myelination that may be one explanation to the higher levels of S100 $(35,36)$.

How specific for brain injury is the protein S100? Why is S100 in serum increased after asphyxia? Several studies have shown that the dimers $\alpha \beta$ and $\beta \beta$ S100 are mainly specific for the nervous system, and present chiefly in the astroglial cells of the CNS $(16,17) . S 100 \beta$ is a neurotrophic protein with a trophic role during development of the nervous system (34). However, overexpression of $\mathrm{S} 100 \beta$ can be deleterious. High concentrations of $\mathrm{S} 100 \beta$ results in a potent activation of inducible nitric oxide synthase (iNOS) and a subsequent generation of nitric oxide (NO), resulting in astrocytic cell death (37). In Alzheimers disease and in Downs syndrom where chronic glial activation occurs, S100 beta levels in several affected brain regions are elevated several-fold compared with age-matched controls (38). Children with Down syndrome regardless of age, have basal levels of S100 comparable to those in neonates (23). The gene encoding $\beta$-S100 protein maps to the distal half of the long arm of human chromosome 21 the Down syndrome region, was first described by Allore in $1988(39,40)$. Of course, it is now known that the S100 family of proteins includes at least thirteen different a-subunits, and the exact subunit composition of the circulating "S100" detected by our assay is inevitably uncertain. However, it is reasonable to assume that the specificity of the assay for $\mathrm{S} 100$ $\mathrm{b}$ will result in the detection of $\alpha \beta$ and $\beta \beta$ multimers predominantly expressed in astroglial tissue.

Recently, a group in Holland reported presence of S100 $\alpha$, and $\beta$ in the tissue of the umbilical cord and placenta (41). The group postulated that for this reason S100 could not be considered as a brain specific marker, and could not be used as a marker of brain injury. However, recently a study on IUGR fetuses showed circulating S100 $\beta$ protein to be increased and correlated with cerebral hemodynamics. In that study no difference in the localization or intensity of S100beta staining in the placental tissues or cord between uncomplicated and IUGR pregnancies was found (25). Even if there might be a certain production of S100 in placenta and in the umbilical cord, that would not have explained the several-fold increased S100 that was observed in this study in infants developing brain injury. Furthermore the half-life of the protein is reported to be even less than the two hours reported earlier (42).

The present study is based on blood samples from the infants during the first days of life. We found the highest values of S100 in the affected infants on day 1, lower on day 2 and 3 but still obviously increased compared with controls. This may indicate progressive cell degradation, in accordance with an 
Table 5. Prediction of outcome in 62 infants with birth asphyxia; sensitivity (sens), specificity (spec), positive predictive value (PPV), negative predictive value (NPV) for hypoxic ischemic encephalopathy (HIE), and cerebral palsy (CP)

\begin{tabular}{|c|c|c|c|c|c|c|c|c|}
\hline & \multicolumn{4}{|c|}{ Moderate or severe HIE } & \multicolumn{4}{|c|}{$\mathrm{CP}$ or death } \\
\hline & SENS & SPEC & PPV & NPV & SENS & SPEC & PPV & NPV \\
\hline Acidosis & 94 & 33 & 67 & 80 & 100 & 25 & 39 & 100 \\
\hline $\mathrm{S} 100>12 \mu \mathrm{g} / \mathrm{L}$ & 50 & 85 & 82 & 55 & 73 & 74 & 50 & 89 \\
\hline $\mathrm{S} 100>12 \mu \mathrm{g} / \mathrm{L}$ and acidosis & 53 & 92 & 90 & 58 & 61 & 78 & 55 & 82 \\
\hline HIE & & & & & 100 & 60 & 53 & 100 \\
\hline Acidosis and HIE & & & & & 100 & 65 & 58 & 100 \\
\hline $\mathrm{S} 100>12 \mu \mathrm{g} / \mathrm{L}$ and HIE & & & & & 61 & 84 & 61 & 84 \\
\hline $\mathrm{S} 100>12 \mu \mathrm{g} / \mathrm{L}$ and HIE and acidosis & & & & & 61 & 80 & 58 & 82 \\
\hline
\end{tabular}

ongoing apoptosis and/or necrosis many hours after the brain injury started, consistent with a secondary damage (9). This is in accordance with a study of adults resuscitated from cardiac arrest showing that increased S100 levels not only on day 1 but also on day 2 correlated with the degree of coma as well as the time of anoxia (22). Consequently repeated values might be useful in prediction of the eventual brain injury.

Most infants who died during the neonatal period had increased S100 values. Of the 10 infants who died (9 during the neonatal period, and one at $11 / 2$ years), 4 had surprisingly low values of S-100, between 0.5 and $6.4 \mathrm{microg} / \mathrm{L}$ on the first day of life, and decreasing levels thereafter. All 4 were delivered by cesarean section for acute obstetrical catastrophes in labor; one cord prolapse, one (who died at $11 / 2$ years) abruption, and two uterine ruptures. All four had CTG abnormalities lasting for more than $15 \mathrm{~min}$. One of them also had fever during labor and was postterm. All 4 had metabolic acidemia at birth, and HIE grade III. All four had birth weights appropriate for gestational age.

It is possible that these lower values of S100 might indicate that the cause of death in these infants was cardiac rather than originating from the brain. Also decreased cerebral circulation due to brain edema, can restrain the passage of S100 through the blood brain barrier to peripheral blood. In the present study we tried to investigate the proportion of infants with a true perinatal brain insult. We only included cases with signs of acute asphyxia, and excluded all known infections and malformations. That the majority of our cases had suffered from intrapartum asphyxia was supported by the finding that $76 \%$ of the infants with available cord $\mathrm{pH}$ had acidosis at birth, and when including also the early postnatal acid base samples, $83 \%$ were acidotic.

Furthermore, it might be difficult to explain the increased S100 on days 1 to 3 in 10 of the 43 infants who had no detectable impairment at 18 mo. Seven of these 10 infants developed moderate HIE in the neonatal period and were severely acidotic at birth. Three of the 10 infants were in breech presentation. However, in three of the infants with no impairment at $18 \mathrm{mo}$ and with $\mathrm{S} 100$ values around $60 \mathrm{microg} / \mathrm{L}$ on day 1 , two had very high serum values of creatinine and one had a high uric acid value in plasma $(631 \mu \mathrm{mol} / \mathrm{L})$. Consequently in these three infants, slow renal elimination can be an explanation of the persistent high levels of S100 but does not explain the first postnatal high value. However, further follow-up may allow more detailed neuropsychological investigation and can possibly detect disabilities that are only subtle in the age of $11 / 2$ year.
We found a significant correlation between acidemia in the infants and the levels of protein S100, and acidemia was associated with moderate and severe encephalopathy as well as with adverse long-term outcome. We also compared the S100 levels between cases with different duration of CTG pathology, thought to reflect different duration or timing of the asphyxia insults. However, infants with abnormal CTG patterns at admission had significantly higher S100, but were not significantly more acidotic than other infants. This may indicate that high levels of S100 may be found after prolonged hypoxia as well as after more severe hypoxia of shorter duration. All infants who died during the neonatal period or subsequently developed CP were acidotic. However, 30 of the 40 infants with available acid base values and who were healthy at follow up also had acidemia. There was an association between the duration of CTG abnormalities and high levels of S100, although very high levels of S100 were also seen in some infants with abnormalities of short duration (in two cases for less than $15 \mathrm{~min}$ ). It seems that the level of S100 rises very fast after a hypoxic insult, since high levels of the protein were detected within a few hours after birth, also in some cases where the clinical signs of asphyxia were of short duration.

There is an agreement concerning the opportunity of therapeutic neuroprotective possibilities after birth asphyxia $(9,10$, 43). After the start of the neurotoxic cascade, there is a therapeutic window, before the secondary energy failure starts and the more permanent brain injury is established (9). To select infants for early interventional cerebral protective treatment, specific methods for identifying the infants at highest risk for developing poor neurologic outcome, are required. S100 might be of interest for timing of the event for the brain damage as well as to discriminate between acute and chronic brain disorders, possibly in combination with assessing glial fibrillary acidic protein (GFAP). High levels of GFAP in combination with normal S100 protein concentrations in CSF, indicates reactive astrogliosis in the CNS (44). A combination of a few very early indicators such as, acid base values, the clinical condition of the infant, Apgar score and HIE, early EEG/aEEG and brain specific proteins such as S100 could possibly be of help in identifying the infants with the highest risk of compromise.

Acknowledgments. The authors thank Susanne Jörning for skilful technical assistance. 


\section{REFERENCES}

1. Palme-Killander C 1992 Methods of resuscitation in low Apgar score newborn infants - a national survey. Acta Paediatr Scand 81:739-744

2. Thornberg E, Thiringer K, Odeback A, Milsom I 1995 Birth asphyxia: incidence, clinical course and outcome in a Swedish population. Acta Paediatr 84:927-932

3. Thorngren-Jerneck K, Herbst A 2001 Low 5-minute Apgar score: a population-based register study of 1 million term births. Obstet Gynecol 98:65-70

4. Levene ML, Kornberg J, Williams TH 1985 The incidence and severity of postasphyxial encephalopathy in full- term infants. Early Hum Dev 11:21-26

5. Sarnat HB, Sarnat MS 1976 Neonatal encephalopathy following fetal distress. A clinical and electroencephalographic study. Arch Neurol 33:696-705

6. Levene MI, Sands C, Grindulis H, Moore JR 1986 Comparison of two methods of predicting outcome in perinatal asphyxia. Lancet 1:67-69

7. Robertson C, Finer N 1985 Term infants with hypoxic-ischemic encephalopathy: outcome at 3.5 years. Dev Med Child Neurol 27:473-484

8. Thorngren-Jerneck K, Ohlsson T, Sandell A, Erlandsson K, Strand SE, Ryding E, Svenningsen NW 2001 Cerebral glucose metabolism measured by positron emission tomography in term newborn infants with hypoxic ischemic encephalopathy. Pediatr Res 49:495-501

9. Wyatt JS, Edwards AD, Azzopardi D, Reynolds EO 1989 Magnetic resonance and near infrared spectroscopy for investigation of perinatal hypoxic-ischaemic brain injury. Arch Dis Child 64(7 Spec No):953-963

10. Levene MI, Evans DJ, Mason S, Brown J 1999 An international network for evaluating neuroprotective therapy after severe birth asphyxia. Semin Perinatol 23:226-233

11. Hagberg H, Thornberg E, Blennow M, Kjellmer I, Lagercrantz H, Thiringer K, Hamberger A, Sandberg M 1993 Excitatory amino acids in the cerebrospinal fluid of asphyxiated infants: relationship to hypoxic-ischemic encephalopathy. Acta Paediatr 82:925-929

12. Blennow M, Hagberg H, Rosengren L 1995 Glial fibrillary acidic protein in the cerebrospinal fluid: a possible indicator of prognosis in full-term asphyxiated newborn infants? Pediatr Res 37:260-264

13. Thornberg E, Thiringer K, Hagberg H, Kjellmer I 1995 Neuron specific enolase in asphyxiated newborns: association with encephalopathy and cerebral function monitor trace. Arch Dis Child Fetal Neonatal Ed 72:F39-F42

14. Savman K, Blennow M, Gustafson K, Tarkowski E, Hagberg H 1998 Cytokine response in cerebrospinal fluid after birth asphyxia. Pediatr Res 43:746-751

15. Blennow M, Savman K, Ilves P, Thoresen M, Rosengren L 2001 Brain-specific proteins in the cerebrospinal fluid of severely asphyxiated newborn infants. Acta Paediatr 90:1171-1175

16. Zimmer DB, Cornwall EH, Landar A, Song W 1995 The S100 protein family: history, function, and expression. Brain Res Bull 37:417-429

17. Kuwano R, Usui H, Maeda T, Araki K, Yamakuni T, Kurihara T, Takahashi Y 1987 Tissue distribution of rat S-100 alpha and beta subunit mRNAs. Brain Res 388:79-82

18. Persson L, Hardemark HG, Gustafsson J, Rundstrom G, Mendel-Hartvig I, Esscher T, Pahlman S 1987 S-100 protein and neuron-specific enolase in cerebrospinal fluid and serum: markers of cell damage in human central nervous system. Stroke 18:911-918

19. Aurell A, Rosengren LE, Karlsson B, Olsson JE, Zbornikova V, Haglid KG 1991 Determination of S-100 and glial fibrillary acidic protein concentrations in cerebrospinal fluid after brain infarction. Stroke 22:1254-1258

20. Missler U, Wiesmann M, Friedrich C, Kaps M 1997 S-100 protein and neuronspecific enolase concentrations in blood as indicators of infarction volume and prognosis in acute ischemic stroke [see comments]. Stroke 28:1956-1960

21. Wunderlich MT, Ebert AD, Kratz T, Goertler M, Jost S, Herrmann M 1999 Early neurobehavioral outcome after stroke is related to release of neurobiochemical markers of brain damage. Stroke 30:1190-1195

22. Rosen H, Rosengren L, Herlitz J, Blomstrand C 1998 Increased serum levels of the S-100 protein are associated with hypoxic brain damage after cardiac arrest. Stroke 29:473-477
23. Lindberg L, Olsson AK, Anderson K, Jogi P 1998 Serum S-100 protein levels after pediatric cardiac operations: a possible new marker for postperfusion cerebral injury [see comments]. J Thorac Cardiovasc Surg 116:281-285

24. Gazzolo D, Vinesi P, Bartocci M, Geloso MC, Bonacci W, Serra G, Haglid KG, Michetti F 1999 Elevated S100 blood level as an early indicator of intraventricular hemorrhage in preterm infants. Correlation with cerebral Doppler velocimetry. J Neurol Sci 170:32-35

25. Gazzolo D, Marinoni E, di Iorio R, Lituania M, Bruschettini PL, Michetti F 2002 Circulating S100beta protein is increased in intrauterine growth-retarded fetuses Pediatr Res 51:215-219

26. Nagdyman N, Komen W, Ko HK, Muller C, Obladen M 2001 Early biochemical indicators of hypoxic-ischemic encephalopathy after birth asphyxia. Pediatr Res 49:502-506

27. Amer-Wahlin I, Herbst A, Lindoff C, Thorngren-Jerneck K, Marsal K, Alling C 2001 Brain-specific NSE, and S-100 proteins in umbilical blood after normal delivery Clin Chim Acta 304:57-63

28. Thorngren-Jerneck K, Alling C 1999 S-100 in term newborn infants with hypoxic ischemic encephalopathy after birth asphyxia. J Neurochem 73(suppl):S198C

29. Amiel-Tison C 1978 A method for neurological evaluation within the first year of life: experience with full-term newborn infants with birth injury. Ciba Found Symp 59:107-137

30. Hagberg B, Hagberg G, Beckung E, Uvebrant P 2001 Changing panorama of cerebral palsy in Sweden. VIII. Prevalence and origin in the birth year period 1991-94. Acta Paediatr 90:271-277

31. 1987 FIGO Guidelines for the use of fetal monitoring. Int J Gynaecol Obstet $12: 159-167$

32. Maschmann J, Erd MA, Heinemann MK, Ziemer G, Speer CP 2000 Evaluation of protein S-100 serum concentrations in healthy newborns and seven newborns with perinatal acidosis. Acta Paediatr 89:553-555

33. Selinfreund RH, Barger SW, Pledger WJ, Van Eldik LJ 1991 Neurotrophic protein S100 beta stimulates glial cell proliferation. Proc Natl Acad Sci USA 88:3554-3558

34. Barger SW, Van Eldik LJ 1992 S100 beta stimulates calcium fluxes in glial and neuronal cells. J Biol Chem 267:9689-9694

35. Dobbing J, Sands J 1978 Head circumference, biparietal diameter and brain growth in fetal and postnatal life. Early Hum Dev 2:81-87

36. Huppi PS, Warfield S, Kikinis R, Barnes PD, Zientara GP, Jolesz FA, Tsuji MK, Volpe JJ 1998 Quantitative magnetic resonance imaging of brain development in premature and mature newborns. Ann Neurol 43:224-235

37. Hu J, Ferreira A, Van Eldik LJ 1997 S100beta induces neuronal cell death through nitric oxide release from astrocytes. J Neurochem 69:2294-2301

38. Griffin WS, Sheng JG, McKenzie JE, Royston MC, Gentleman SM, Brumback RA, Cork LC, Del Bigio MR, Roberts GW, Mrak RE 1998 Life-long overexpression of S100beta in Down's syndrome: implications for Alzheimer pathogenesis. Neurobiol Aging 19:401-405

39. Allore R, O'Hanlon D, Price R, Neilson K, Willard HF, Cox DR, Marks A, Dunn RJ 1988 Gene encoding the beta subunit of S100 protein is on chromosome 21: implications for Down syndrome. Science 239:1311-1313

40. Landry CF, Ivy GO, Dunn RJ, Marks A, Brown IR 1989 Expression of the gene encoding the beta-subunit of S-100 protein in the developing rat brain analyzed by in situ hybridization. Brain Res Mol Brain Res 6:251-262

41. Wijnberger LD, Nikkels PG, van Dongen AJ, Noorlander CW, Mulder EJ, Schrama LH, Visser GH 2002 Expression in the placenta of neuronal markers for perinatal brain damage. Pediatr Res 51:492-496

42. Jonsson H, Johnsson P, Hoglund P, Alling C, Blomquist S 2000 Elimination of S100B and renal function after cardiac surgery J Cardiothorac Vasc Anesth 14:698-701

43. Edwards AD, Wyatt JS, Thoresen M 1998 Treatment of hypoxic-ischaemic brain damage by moderate hypothermia. Arch Dis Child Fetal Neonatal Ed 78:F85-F88

44. Rosengren LE, Ahlsen G, Belfrage M, Gillberg C, Haglid KG, Hamberger A 1992 A sensitive ELISA for glial fibrillary acidic protein: application in CSF of children. J Neurosci Methods 44:113-119 